\title{
Analisis Suseptibilitas Magnetik dan Kandungan Logam Berat pada Tanah Lapisan Atas di Beberapa Ruas Jalan Kota Bukittinggi
}

\author{
Intan Suri Maharani*, Arif Budiman \\ Laboratorium Fisika Bumi, Jurusan Fisika \\ Fakultas Matematika dan Ilmu Pengetahuan Alam Universitas Andalas \\ Kampus Unand Limau Manis, Padang, 25163 Indonesia \\ *intan.surimaharani1804@gmail.com
}

\begin{abstract}
ABSTRAK
Telah dilakukan identifikasi pencemaran logam berat pada tanah lapisan atas dengan menggunakan metode suseptibilitas magnetik dan spektroskopi di ruas jalan raya Kota Bukittinggi. Sampel tanah dari 41 titik diambil di Jalan Veteran, Jalan Bypass, dan Jalan Sutan Syahrir pada kedalaman $10 \mathrm{~cm}$ dari permukaan tanah dengan jarak $50 \mathrm{~cm}$ dari pinggir jalan dan jarak spasi antar sampel $200 \mathrm{~m}$. Hasil pengukuran menunjukkan bahwa sampel memiliki nilai suseptibilitas magnetik antara $297,9 \times 10^{-8} \mathrm{~m}^{3} / \mathrm{kg}$ (B02) sampai $1604,2 \times 10^{-8} \mathrm{~m}^{3} / \mathrm{kg}$ (V06). Penentuan jenis dan kandungan logam berat dilakukan pada lima sampel yaitu sampel B02, B01, S03, V10, dan V06. Hasil uji XRF menunjukkan bahwa sampel mengandung logam berat $\mathrm{Pb}, \mathrm{Cu}, \mathrm{Zn}, \mathrm{Mn}$, dan $\mathrm{Ni}$. Suseptibilitas magnetik dan konsentrasi total logam berat sampel memiliki korelasi positif yang kuat dengan nilai koefisien korelasi sebesar 0,932. Begitu juga untuk hubungan antara suseptibilitas magnetik sampel dan konsentrasi masing-masing logam $\mathrm{Pb}$, $\mathrm{Cu}, \mathrm{Zn}$, dan $\mathrm{Mn}$ dengan nilai koefisien korelasi berturut-turut yaitu 0,929, 0,967, 0,871, dan 0,994. Kandungan logam berat yang sudah melewati ambang batas pada tanah adalah $\mathrm{Pb}(\mathrm{V} 10$ dan V06), $\mathrm{Cu}$ (B01, S03, V10, V06), dan Zn (B02, B01, S03, V10, V06).
\end{abstract}

Kata kunci: logam berat, suseptibilitas magnetik, tanah lapisan atas

\section{ABSTRACT}

Heavy metal pollution on topsoil with magnetic susceptibility and spectroscopy on Bukittinggi's highway has been identified. The 41 points of soil samples took from Veteran, Bypass, and Sutan Syahrir street with $10 \mathrm{~cm}$ depth from the ground, $50 \mathrm{~cm}$ from the edge of the road and $200 \mathrm{~m}$ from each sample. The result shows that the samples have magnetic susceptibility values between $297,9 \times 10^{-8} \mathrm{~m}^{3} / \mathrm{kg}^{(B 02)}-$ $1604,2 \times 10^{-8} \mathrm{~m}^{3} / \mathrm{kg}$ (V06). Determination of the type and content of heavy metals is done on five samples, which are B02, B01, S03, V10, and V06. The XRF's result shows that the samples contain $\mathrm{Pb}, \mathrm{Cu}, \mathrm{Zn}$, $\mathrm{Mn}$, and $\mathrm{Ni}$. The magnetic susceptibility and heavy metal's concentration have a strong positive correlation with 0,932 correlation coefficient value. The samples magnetic susceptibility with concentration in each metal $\mathrm{Pb}, \mathrm{Cu}, \mathrm{Zn}$, and $\mathrm{Mn}$ had 0,929, 0,967,0,871 and 0,994 correlation coefficient value respectively. The heavy metal that has already crossed the treshold are $\mathrm{Pb}$ (V10 dan V06), $\mathrm{Cu}$ (B01, S03, V10, V06), and Zn (B02, B01, S03, V10, V06).

Keywords: heavy metal, magnetic susceptibility, topsoil

\section{PENDAHULUAN}

Logam berat adalah suatu unsur logam yang memiliki densitas relatif tinggi. Logam berat merupakan bahan pencemar yang berbahaya karena tidak dapat dihancurkan (non degradable) oleh organisme hidup di lingkungan (Rochyatun dan Rozak, 2007). Pada manusia logam berat dapat masuk melalui udara serta melalui makanan yang berasal dari tumbuhan dan hewan yang hidup di lingkungan yang terkontaminasi logam berat. Logam berat yang terdapat pada tubuh manusia akan mengganggu fungsi komponen sel vital sehingga menyebabkan berbagai jenis penyakit kanker (Han dkk., 2018).

Secara umum lapisan tanah tersusun dari tanah lapisan atas, tanah lapisan tengah, tanah lapisan bawah, dan tanah lapisan batuan induk. Tanah lapisan atas merupakan penerima dari berbagai macam polutan terutama logam berat yang menumpuk dalam waktu lama sehingga akan terus meningkat dari waktu ke waktu. Oleh karena itu, tanah lapisan atas dapat digunakan sebagai indikator untuk mengetahui tingkat pencemaran logam berat.

Di daerah perkotaan, yang menjadi sumber utama pencemaran logam berat pada tanah lapisan atas selain dari emisi pabrik adalah emisi kendaraan bermotor (Johansson dkk., 2009). Logam berat yang dihasilkan oleh emisi kendaraan bermotor adalah $\mathrm{Pb}, \mathrm{Cd}, \mathrm{Cu}, \mathrm{Zn}, \mathrm{Mn}$, dan $\mathrm{Ni}$ (Li dkk., 2001; Sezgin dkk., 2003). Logam berat tersebut berasal dari gesekan mesin, karatan pada kendaraan, gas buang kendaraan dari hasil pembakaran yang tidak sempurna, pemakaian 144 
kampas rem, ban, dan komponen kendaraan lainnya. Logam berat tersebut terbang bersama udara, kemudian jatuh dan mengendap di permukaan tanah (Johansson dkk., 2009; Yulius dan Afdal, 2014).

Logam berat dapat diidentifikasi menggunakan metode spektrometri seperti UV-Vis Spectrometry, Inductively Coupled Plasma (ICP), Atomic Absorption Spectroscopy (AAS), dan $X$-Ray Fluorescence (XRF). Jika metode ini diterapkan pada penelitian yang melibatkan sampel yang banyak akan membutuhkan waktu yang lama dan biaya yang besar. Hal ini dapat diatasi dengan menggunakan metode suseptibilitas magnetik terlebih dahulu. Tanah yang mengandung logam berat akan memiliki nilai suseptibilitas magnetik yang lebih tinggi daripada tanah yang tidak mengandung logam berat (Lu, dkk., 2010). Kelebihan dari metode suseptibilitas magnetik yaitu lebih sederhana, cepat, ekonomis, dan tidak merusak atau bersifat non destruktif (Karimi dkk., 2011). Beberapa sampel yang mewakili sebaran nilai suseptibilitas magnetik dari yang terendah hingga tertinggi dipilih untuk menentukan jenis dan konsentrasi logam berat menggunakan salah satu instrumen dari metode spektrometri. Selanjutnya ditentukan hubungan antara nilai suseptibilitas magnetik dengan jenis dan konsentrasi logam berat pada sampel.

Beberapa peneliti telah melakukan penelitian mengenai identifikasi logam berat yang berasal dari emisi kendaraan bermotor. Karimi dkk. (2011) melakukan penelitian hubungan antara suseptibilitas magnetik dan logam berat pada tanah lapisan atas di daerah perkotaan Isfahan, Iran. Penelitian ini menggunakan alat Bartington susceptibility meter dan Inductively Coupled Plasma Mass Spectrometry (ICP-MS). Hasil penelitian menunjukkan bahwa $\mathrm{Pb}, \mathrm{Cu}$, $\mathrm{Zn}$, dan Ba memiliki korelasi yang signifikan dengan suseptibilitas magnetik. Namun As, Sr, $\mathrm{Cd}, \mathrm{Mn}, \mathrm{Cr}$ dan $\mathrm{V}$ tidak memiliki korelasi yang signifikan dengan suseptibilitas magnetik. Yulius dan Afdal (2014) telah mengidentifikasi sebaran logam berat pada tanah lapisan atas dan hubungannya dengan suseptibilitas magnetik di beberapa ruas jalan di sekitar Pelabuhan Teluk Bayur Padang. Konsentrasi logam berat memiliki korelasi dengan suseptibilitas magnetik, dengan koefisien korelasi 0,50 untuk $\mathrm{Pb}, 0,31$ untuk $\mathrm{Cu}, 0,12$ untuk $\mathrm{Cd}$, dan 0,17 untuk $\mathrm{Zn}$. Liu dkk. (2016) melakukan penelitian sebaran suseptibilitas magnetik tanah dan hubungannya dengan pencemaran logam berat di Kota Kaifeng, China. Hasil penelitian menunjukkan bahwa logam berat $\mathrm{As}, \mathrm{Cd}, \mathrm{Cr}, \mathrm{Cu}, \mathrm{Ni}, \mathrm{Pb}$, dan $\mathrm{Zn}$ yang terdapat dalam sampel memiliki korelasi positif dengan nilai suseptibilitasnya.

Selanjutnya akan dilakukan penelitian untuk mengetahui hubungan nilai suseptibilitas dengan konsentrasi logam berat yang berasal dari emisi kendaraan bermotor di Kota Bukittinggi. Bukittinggi merupakan kota wisata dengan jumlah wisatawan yang terus mengalami peningkatan setiap tahunnya. Di samping itu, Kota Bukittinggi berada pada posisi strategis Jalur Lintas Sumatera yang menghubungkan Kota Padang, Medan, Palembang, dan Pekanbaru. Menurut Badan Pusat Statistik Kota Bukittinggi (2017), jumlah wisatawan yang berkunjung ke Kota Bukittinggi pada tahun 2016 yaitu sebanyak 5.538.896 orang dan jumlah kendaraan bermotor di Kota Bukittinggi pada tahun 2016 yaitu sebanyak 42.640 unit. Tingginya angka kendaraan bermotor yang melintasi setiap jalan raya di Kota Bukittinggi akan berdampak pada tingginya tingkat pencemaran logam berat yang dihasilkan oleh emisi kendaraan bermotor tersebut. Oleh karena itu perlu dilakukan penelitian untuk mengidentifikasi sebaran logam berat pada tanah lapisan atas di beberapa ruas jalan utama Kota Bukittinggi. Di samping itu di daerah ini belum pernah dilakukan penelitian serupa.

\section{METODE}

Pengambilan sampel dilakukan di tiga ruas jalan raya Kota Bukittinggi yaitu Jalan Veteran, Jalan Bypass, dan Jalan Sutan Syahrir. Sampel yang diambil berupa tanah lapisan atas dengan kedalaman $10 \mathrm{~cm}$ dari permukaan tanah pada jarak $50 \mathrm{~cm}$ dari pinggir jalan dan jarak spasi antar sampel $200 \mathrm{~m}$ sehingga diperoleh 41 titik pengambilan sampel (Gambar 1). 


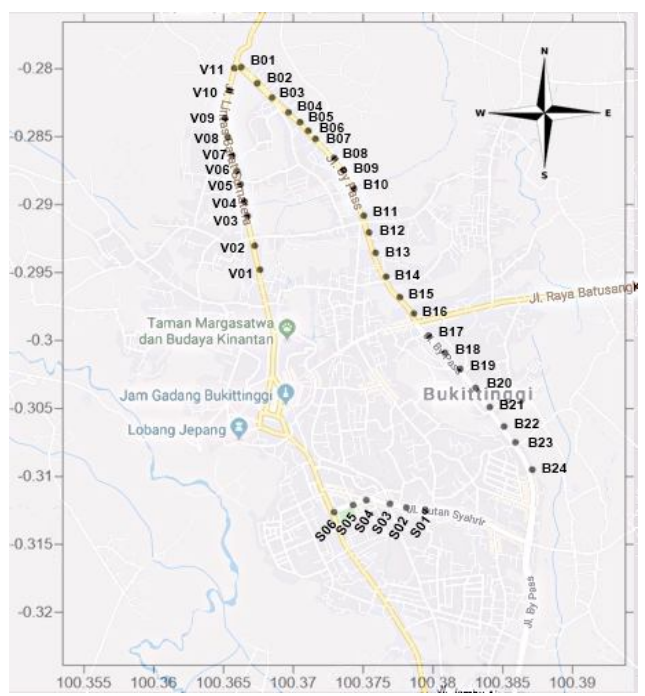

Gambar 1 Titik-titik lokasi pengambilan sampel

Pengambilan sampel dilakukan menggunakan pipa PVC dan sekop, kemudian dimasukkan ke dalam plastic ziplock lalu dibawa ke Laboratorium Fisika Bumi Universitas Andalas. Sampel yang telah diambil dikeringkan pada temperatur kamar selama 4 sampai 5 hari. Pengeringan sampel dilakukan agar uap air yang terkandung pada sampel tanah berkurang. Sampel tanah yang sudah dikeringkan tersebut lalu digerus dan kemudian diayak menggunakan saringan 100 mesh. Sampel tanah tersebut dimasukkan ke dalam sample holder. Selanjutnya dilakukan pengukuran suseptibilitas magnetik menggunakan Bartington Susceptibility Meter MS2B dengan sensor MS2B menggunakan 15 arah pengukuran. Data dari hasil pengukuran dicatat, kemudian diolah menggunakan program Matlab 2015a. Pengukuran jenis dan konsentrasi logam berat dilakukan terhadap lima buah sampel di Laboratorium Kimia Instrumen Universitas Negeri Padang menggunakan X-Ray Fluorescence Panalytical Epsilon 3.

\section{HASIL DAN DISKUSI}

\subsection{Pengukuran Suseptibilitas Magnetik Sampel Tanah}

Berdasarkan Gambar 2 dapat dilihat pola nilai suseptibilitas magnetik untuk masingmasing lokasi pengambilan sampel. Nilai suseptibilitas magnetik memiliki tren yang sama yaitu fluktuatif untuk tiap lokasi. Perbedaan tingkat aktivitas lalu lintas di lokasi pengambilan sampel dan keadaan sekitar lokasi dapat mempengaruhi nilai suseptibilitas magnetik.

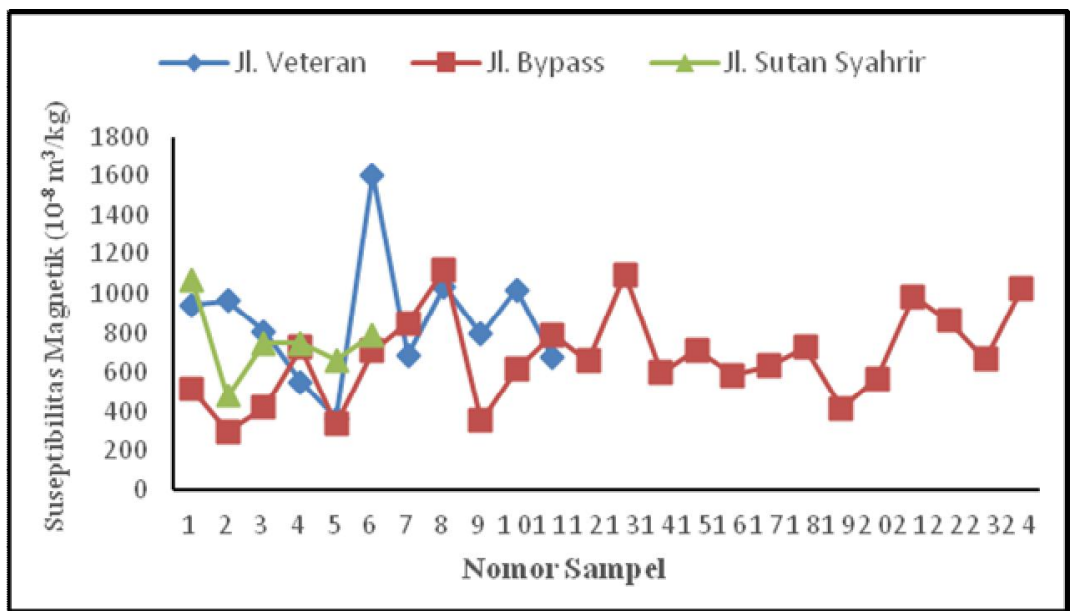

Gambar 2 Grafik nilai suseptibilitas magnetik pada masing-masing lokasi pengambilan sampel

Jalan Veteran memiliki nilai suseptibilitas magnetik lebih tinggi dibandingkan dengan Jalan Bypass dan jalan Sutan Syahrir. Jalan Sutan Syahrir memiliki rata-rata nilai suseptibilitas 
magnetik yang relatif tinggi namun masih di bawah nilai suseptibilitas magnetik Jalan Veteran. Sedangkan untuk Jalan Bypass memiliki rata-rata nilai suseptibilitas magnetik yang paling rendah.

Nilai suseptibilitas magnetik sampel tanah dari 41 titik pengambilan sampel di lokasi penelitian dapat dilihat pada Tabel 1 . Untuk seluruh data, nilai suseptibilitas magnetik sampel berkisar dari $297,9 \times 10^{-8} \mathrm{~m}^{3} / \mathrm{kg}$ sampai $1604,2 \times 10^{-8} \mathrm{~m}^{3} / \mathrm{kg}$ dengan nilai rata-rata $737,37 \times 10^{-8}$ $\mathrm{m}^{3} / \mathrm{kg}$.

Tabel 1 Nilai suseptibilitas magnetik sampel tanah

\begin{tabular}{|c|c|c|c|c|c|}
\hline Lokasi & No. & $\begin{array}{c}\text { Kode } \\
\text { sampel }\end{array}$ & $\begin{array}{l}\text { Koordinat } \\
\text { lintang }\left({ }^{\circ}\right)\end{array}$ & $\begin{array}{c}\text { Koordinat } \\
\text { bujur }\left({ }^{\circ}\right)\end{array}$ & $\begin{array}{c}\text { Suseptibilitas } \\
\text { Magnetik }\left(10^{-8} \mathrm{~m}^{3} / \mathrm{kg}\right)\end{array}$ \\
\hline \multirow{11}{*}{$\begin{array}{c}\text { Jalan } \\
\text { Veteran }\end{array}$} & 1 & V01 & $-0,2947839$ & 100,3676059 & 945,1 \\
\hline & 2 & V02 & $-0,2930247$ & 100,3672287 & 964,9 \\
\hline & 3 & V03 & $-0,2908444$ & 100,3667355 & 807,4 \\
\hline & 4 & V04 & $-0,2897752$ & 100,3665011 & 551,0 \\
\hline & 5 & V05 & $-0,2885032$ & 100,3662182 & 365,7 \\
\hline & 6 & V06 & $-0,2875242$ & 100,3659530 & 1604,2 \\
\hline & 7 & V07 & $-0,2863903$ & 100,3656267 & 690,5 \\
\hline & 8 & V08 & $-0,2850181$ & 100,3652962 & 1035,5 \\
\hline & 9 & V09 & $-0,2836508$ & 100,3651067 & 794,6 \\
\hline & 10 & V10 & $-0,2815825$ & 100,3654229 & 1020,4 \\
\hline & 11 & V11 & $-0,2799595$ & 100,3657753 & 675,9 \\
\hline \multirow{24}{*}{$\begin{array}{l}\text { Jalan } \\
\text { Bypass }\end{array}$} & 12 & B01 & $-0,2798951$ & 100,3662547 & 513,1 \\
\hline & 13 & B02 & $-0,2810716$ & 100,3674141 & 297,9 \\
\hline & 14 & B03 & $-0,2821334$ & 100,3684756 & 420,4 \\
\hline & 15 & B04 & $-0,2832123$ & 100,3696514 & 728,3 \\
\hline & 16 & B05 & $-0,2839355$ & 100,3704795 & 335,5 \\
\hline & 17 & B06 & $-0,2845678$ & 100,3710606 & 710,2 \\
\hline & 18 & B07 & $-0,2851639$ & 100,3715829 & 849,6 \\
\hline & 19 & B08 & $-0,2865556$ & 100,3729240 & 1122,3 \\
\hline & 20 & B09 & $-0,2874619$ & 100,3735828 & 354,4 \\
\hline & 21 & B10 & $-0,2888318$ & 100,3743362 & 616,0 \\
\hline & 22 & B11 & $-0,2908132$ & 100,3750430 & 791,4 \\
\hline & 23 & B12 & $-0,2920494$ & 100,3754178 & 657,8 \\
\hline & 24 & B13 & $-0,2935440$ & 100,3758912 & 1097,0 \\
\hline & 25 & B14 & $-0,2953052$ & 100,3766422 & 597,5 \\
\hline & 26 & B15 & $-0,2968049$ & 100,3776266 & 715,0 \\
\hline & 27 & B16 & $-0,2980102$ & 100,3786385 & 584,7 \\
\hline & 28 & B17 & $-0,2996279$ & 100,3796808 & 632,3 \\
\hline & 29 & B18 & $-0,3008942$ & 100,3808486 & 725,9 \\
\hline & 30 & B19 & $-0,3020867$ & 100,3819490 & 416,1 \\
\hline & 31 & B20 & $-0,3034848$ & 100,3830484 & 569,3 \\
\hline & 32 & B21 & $-0,3048983$ & 100,3840646 & 987,5 \\
\hline & 33 & B22 & $-0,3063259$ & 100,3850862 & 860,9 \\
\hline & 34 & B23 & $-0,3074927$ & 100,3859009 & 669,1 \\
\hline & 35 & B24 & $-0,3094996$ & 100,3871092 & 1030,3 \\
\hline \multirow{6}{*}{$\begin{array}{c}\text { Jalan } \\
\text { Sutan } \\
\text { Syahrir }\end{array}$} & 36 & S01 & $-0,3125328$ & 100,3794415 & 1068,1 \\
\hline & 37 & S02 & $-0,3122884$ & 100,3780893 & 478,4 \\
\hline & 38 & S03 & $-0,3120104$ & 100,3769128 & 746,6 \\
\hline & 39 & S04 & $-0,3117352$ & 100,3752254 & 749,0 \\
\hline & 40 & S05 & $-0,3120946$ & 100,3742805 & 661,3 \\
\hline & 41 & S06 & $-0,3126139$ & 100,3729086 & 791,2 \\
\hline
\end{tabular}

Jalan Veteran memiliki sebelas sampel dengan nilai suseptibilitas magnetik berkisar dari $365,7 \times 10^{-8} \mathrm{~m}^{3} / \mathrm{kg}$ sampai $1604,2 \times 10^{-8} \mathrm{~m}^{3} / \mathrm{kg}$ dan nilai rata-rata $859,6 \times 10^{-8} \mathrm{~m}^{3} / \mathrm{kg}$. Jalan Bypass memiliki 24 sampel dengan nilai suseptibilitas magnetik dari $297,9 \times 10^{-8} \mathrm{~m}^{3} / \mathrm{kg}$ sampai $1122,3 \times 10^{-8} \mathrm{~m}^{3} / \mathrm{kg}$ dan nilai rata-rata $708,1 \times 10^{-8} \mathrm{~m}^{3} / \mathrm{kg}$. Jalan Sutan Syahrir memiliki enam sampel dengan nilai suseptibilitas magnetik dari $478,4 \times 10^{-8} \mathrm{~m}^{3} / \mathrm{kg}$ sampai $1068,1 \times 10^{-8} \mathrm{~m}^{3} / \mathrm{kg}$ dan nilai rata-rata $749,1 \times 10^{-8} \mathrm{~m}^{3} / \mathrm{kg}$. Selanjutnya dilakukan penentuan unsur dan konsentrasi logam berat dengan menggunakan XRF.

\subsection{Hubungan Suseptibilitas Magnetik dan Total Konsentrasi Logam Berat}

Penentuan konsentrasi logam berat dilakukan pada lima buah sampel dengan nilai suseptibilitas magnetik terendah hingga tertinggi menggunakan XRF. Logam berat yang dianalisis adalah logam berat yang dihasilkan oleh aktivitas kendaraan bermotor yaitu $\mathrm{Pb}, \mathrm{Cd}$, $\mathrm{Cu}, \mathrm{Zn}, \mathrm{Mn}$, dan Ni (Li dkk., 2001; Sezgin dkk., 2003). 
Tabel 2 Konsentrasi Logam Berat

\begin{tabular}{|c|c|c|c|c|c|c|c|c|c|}
\hline \multirow{2}{*}{ No } & \multirow{2}{*}{$\begin{array}{c}\text { Kode } \\
\text { Sampel }\end{array}$} & \multirow{2}{*}{$\begin{array}{c}\text { Suseptibilitas } \\
\text { Magnetik } \\
\left(\chi_{m}\right) \\
\left(10^{-8} \mathrm{~m}^{3} / \mathrm{kg}\right)\end{array}$} & \multicolumn{6}{|c|}{ Konsentrasi Logam Berat (ppm) } & \multirow{2}{*}{ Total } \\
\hline & & & $\mathbf{P b}$ & Cd & $\mathbf{C u}$ & $\mathbf{Z n}$ & Mn & $\mathbf{N i}$ & \\
\hline 1 & B02 & 297,9 & 90 & - & - & $330 *$ & 1550 & - & 1970 \\
\hline 2 & B 01 & 513,1 & 110 & - & $170 *$ & $1030 *$ & 1900 & - & 3210 \\
\hline 3 & S03 & 746,6 & 110 & - & $140 *$ & $870 *$ & 2090 & - & 3210 \\
\hline 4 & V 10 & 1020,4 & $220 *$ & - & $300 *$ & $730 *$ & 2340 & 30 & 3620 \\
\hline 5 & V06 & 1604,2 & $640 *$ & - & $740 *$ & $4190 *$ & 3190 & 20 & 8780 \\
\hline
\end{tabular}

Tabel 2 menunjukkan hasil uji XRF pada lima buah sampel untuk beberapa jenis logam berat di lokasi pengambilan sampel. Dari lima buah sampel yang diuji XRF ini dapat dilihat bahwa semua sampel mengandung logam berat yang konsentrasinya sudah melewati ambang batas. Logam berat $\mathrm{Pb}$ sudah melewati ambang batas pada titik V10 dan V06. Logam berat $\mathrm{Cd}$ tidak terdeteksi pada semua sampel. Hal ini menunjukkan bahwa kandungan logam berat $\mathrm{Cd}$ memiliki nilai yang sangat kecil atau mendekati nol. Logam berat $\mathrm{Cu}$ nilainya tidak terdeteksi pada sampel B02 sedangkan pada sampel B01, S03, V10, dan V06 sudah memiliki kandungan logam berat di atas ambang batas. Seluruh sampel memiliki kandungan logam berat $\mathrm{Zn}$ di atas ambang batas. Logam berat Mn dan Ni pada seluruh sampel memiliki konsentrasi yang masih berada di bawah ambang batas. Berdasarkan hasil uji XRF ini dapat disimpulkan bahwa tanah lapisan atas di lokasi pengambilan sampel mengandung logam berat $\mathrm{Pb}, \mathrm{Cu}, \mathrm{Zn}, \mathrm{Mn}$, dan $\mathrm{Ni}$ yang merupakan polutan yang berasal emisi kendaraan bermotor. Berikut adalah grafik perubahan konsentrasi logam berat terhadap nilai suseptibilitas magnetik terendah hingga tertinggi.

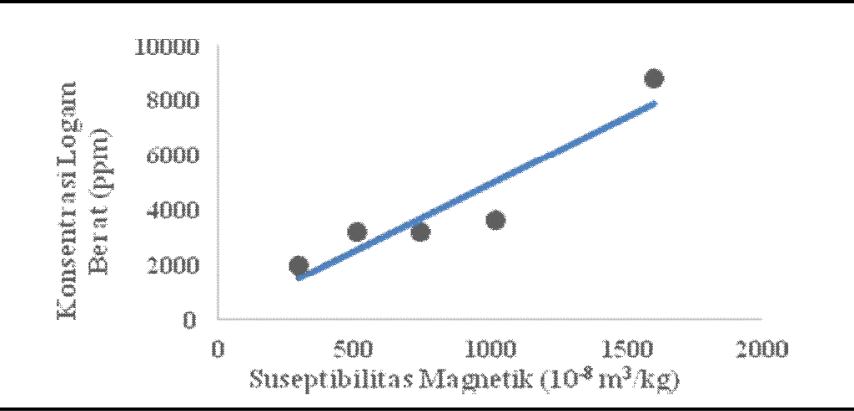

Gambar 3 Grafik hubungan total konsentrasi logam berat terhadap nilai suseptibilitas magnetik sampel

Grafik hubungan antara konsentrasi logam berat terhadap nilai suseptibilitas magnetik pada kelima sampel dapat dilihat pada Gambar 2. Persamaan regresi linier untuk hubungan tersebut ditunjukan pada Persamaan 1.

$$
y=4,8927 x+65,5420
$$

dengan $x$ adalah nilai suseptibilitas magnetik $\left(10^{-8} \mathrm{~m}^{3} / \mathrm{kg}\right)$ dan $y$ adalah konsentrasi logam berat (ppm) dengan nilai koefisien korelasi sebesar 0,932. Nilai ini menunjukkan hubungan yang kuat antara suseptibilitas magnetik dengan kandungan logam berat. Semakin besar nilai suseptibilitas magnetik maka semakin besar pula jumlah kandungan logam berat yang terdapat pada sampel. Berikut akan dianalisis hubungan antara suseptibilitas magnetik dengan masingmasing logam berat.

\subsection{Hubungan Suseptibilitas Magnetik dan Konsentrasi Masing-Masing Logam Berat}

Grafik hubungan antara konsentrasi logam berat $\mathrm{Pb}, \mathrm{Cu}, \mathrm{Zn}$, dan $\mathrm{Mn}$ terhadap nilai suseptibilitas magnetik dapat dilihat pada Gambar 3. Grafik hubungan antara konsentrasi logam berat terhadap nilai suseptibilitas magnetik untuk masing-masing logam $\mathrm{Pb}, \mathrm{Cu}, \mathrm{Zn}$, dan $\mathrm{Mn}$ memiliki nilai koefisien korelasi berturut-turut sebesar 0,929, 0,967, 0,871, dan 0,994. 


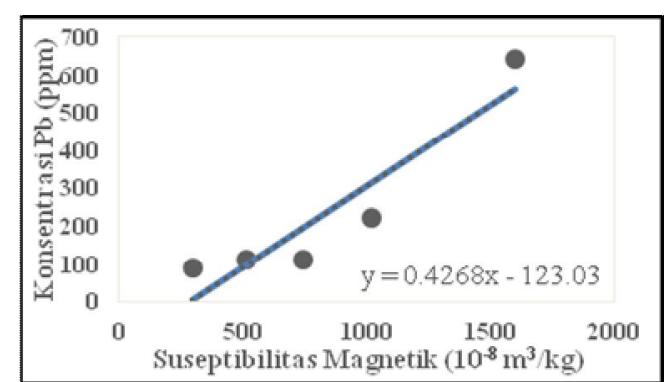

a

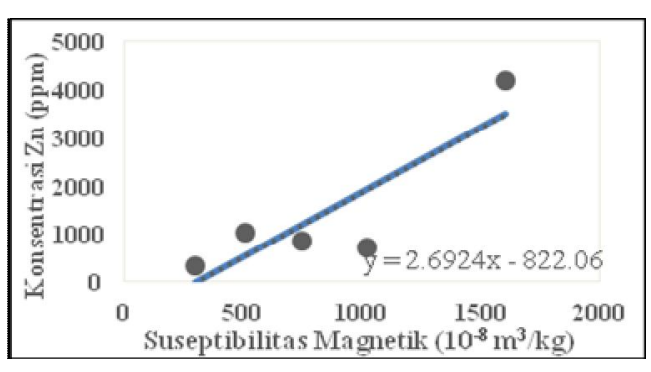

c

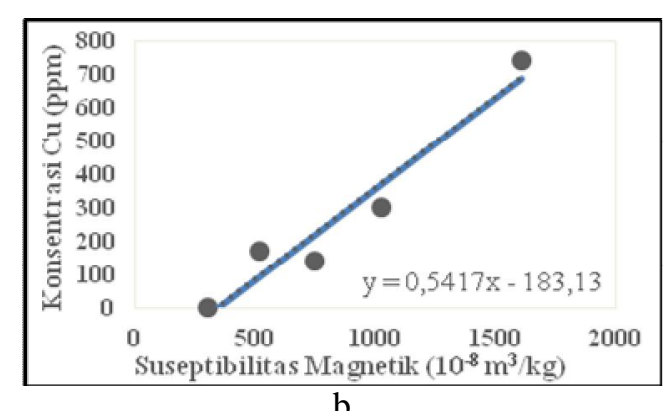

$\mathrm{b}$

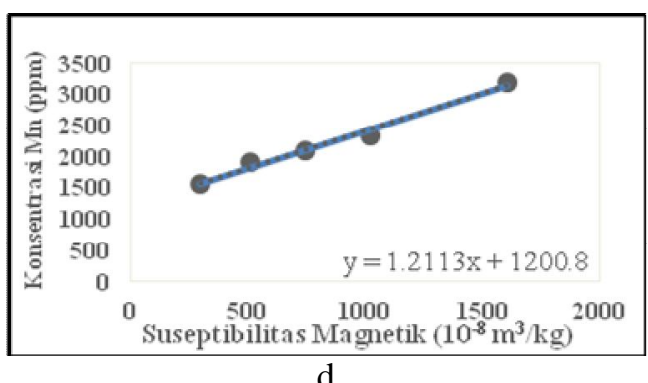

d

Gambar 4 Grafik hubungan konsentrasi logam berat (a) $\mathrm{Pb}$ (b) $\mathrm{Cu}$ (c) $\mathrm{Zn}$ (d) Mn terhadap nilai suseptibilitas magnetik masing-masing sampel

Berdasarkan persamaan regresi linier pada grafik, dapat ditentukan nilai ambang batas suseptibilitas magnetik untuk logam berat $\mathrm{Pb}$ sebesar $756,865 \times 10^{-8} \mathrm{~m}^{3} / \mathrm{kg}$. Berdasarkan nilai suseptibilitas magnetik yang diperoleh pada seluruh sampel, dapat dilihat bahwa terdapat 25 sampel yang berada di bawah batas ambang dan 16 sampel yang berada di atas batas ambang suseptibilitas magnetik di lokasi pengambilan sampel. Nilai ambang batas suseptibilitas magnetik untuk logam berat $\mathrm{Cu}$ sebesar $522,670 \times 10^{-8} \mathrm{~m}^{3} / \mathrm{kg}$ yang memberi gambaran bahwa terdapat 8 sampel yang berada di bawah batas ambang suseptibilitas magnetik dan 33 sampel yang berada di atas batas ambang suseptibilitas magnetik. Untuk logam berat $\mathrm{Zn}$ diperoleh nilai ambang batas suseptibilitas magnetik sebesar $416,750 \times 10^{-8} \mathrm{~m}^{3} / \mathrm{kg}$ yang berarti terdapat 5 sampel dengan nilai suseptibilitas magnetik di bawah batas ambang dan 36 sampel yang berada di atas batas ambang. Logam berat Mn memiliki ambang batas nilai suseptibilitas magnetik sebesar $2310,90 \times 10^{-8} \mathrm{~m}^{3} / \mathrm{kg}$ yang memberi gambaran bahwa untuk saat ini seluruh sampel tanah lapisan atas di daerah penelitian memiliki konsentrasi Mn yang masih berada di bawah ambang batas.

\section{KESIMPULAN}

Berdasarkan hasil penelitian yang telah dilakukan diperoleh kesimpulan bahwa nilai suseptibilitas magnetik berkisar dari $297,9 \times 10^{-8} \mathrm{~m}^{3} / \mathrm{kg}$ sampai $1604,2 \times 10^{-8} \mathrm{~m}^{3} / \mathrm{kg}$. Nilai suseptibilitas magnetik memiliki tren yang sama yaitu fluktuatif untuk tiap lokasi. Rata-rata nilai suseptibilitas tertinggi berada di Jalan Veteran sedangkan untuk rata-rata nilai suseptibilitas terendah berada di Jalan Bypass. Hubungan nilai suseptibilitas magnetik dan konsentrasi total logam berat sampel memiliki korelasi linier yang kuat dengan nilai koefisien korelasi mendekati satu. Hubungan nilai suseptibilitas magnetik dengan konsentrasi logam berat $\mathrm{Pb}, \mathrm{Cu}, \mathrm{Zn}$, dan $\mathrm{Mn}$ yang dihasilkan oleh emisi kendaraan bermotor juga memiliki korelasi linier yang kuat dengan nilai koefisien korelasi mendekati satu. Nilai ini menunjukkan hubungan yang kuat antara suseptibilitas magnetik dengan kandungan logam berat. Semakin besar nilai suseptibilitas magnetik maka semakin besar juga konsentrasi logam berat yang terkandung dalam sampel. Berdasarkan hubungan antara nilai suseptibilitas magnetik dan konsentrasi logam berat pada lima sampel uji, dapat dikatakan bahwa sebagian besar dari seluruh sampel yang diambil di ruas jalan raya Kota Bukittinggi mengandung logam berat yang berasal dari emisi kendaraan bermotor dengan konsentrasi yang telah melebihi ambang batas. 


\section{DAFTAR PUSTAKA}

Erfandi, D. dan Juarsah, I., Konservasi Tanah Menghadapi Perubahan Iklim (Badan Penelitian dan Pengembangan Tanah, Jakarta, 2014).

Han, W., Gao, G., Geng, J., Li, Y., dan Wang, Y., "Ecological and Health

Risks Assessment and Spatial Distribution of Residual Heavy Metals in the Soil of an E-Waste Circular Economy Park in Tianjin, China", Chemosphere, 197, 325-335 (2018).

Johansson, C., Norman, M., dan Burman, L., "Road Traffic Emission Factors for Heavy Metals", Atmospheric Environment, 43, 4681-4688 (2009).

Karimi, R., Ayoubi, S., Jalalian, A., Sheikh-Hosseini, A.R., dan Afyuni, M., "Relationships Between Magnetic Susceptibility and Heavy Metals in Urban Topsoils in the Arid Region of Isfahan, Central Iran”, Journal of Applied Geophysics, 74, 1-7 (2011).

Li, X., Poon, C., dan Liu, P.S., "Heavy Metal Contamination of Urban Soils and Street Dusts in Hong Kong", Applied Geochemistry, 16, 1361-1368 (2001).

Liu, D., Ma, J., Sun, Y., dan Li, Y., "Spatial Distribution of Soil Magnetic Susceptibility and Correlation with Heavy Metal Pollution in Kaifeng City, China", Catena, 139, 53-60 (2016).

Lu, S., Wang, H. dan Guo, J., 2010 "Magnetic Response of Heavy Metals Pollution in Urban Soils: Magetic Proxy Parameters as an Indicator of Heavy Metals Pollution", World Congress of Soil Science Soil Solutions for a Changing World, Zhejiang University, China.

Rahmi, U. A., Kota Bukittinggi dalam Angka (Badan Pusat Statistik Kota Bukittinggi, Bukittinggi, 2017).

Rochyatun, E. dan Rozak, A., "Pemantauan Kadar Logam Berat dalam Sedimen di Perairan Teluk Jakarta", Makara Sains, 11, 28-36 (2007).

Sezgin, N., Ozcan, H.K., Demir, G., Nemlioglu, S., dan Bayat, C., "Determination of Heavy Metal Concentrations in Street Dusts in Istanbul E-5 Highway", Environment International, 29, 979- 985 (2003).

Yulius, U. dan Afdal, "Identifikasi Sebaran Logam Berat pada Tanah Lapisan Atas dan Hubungannya dengan Suseptibilitas Magnetik di Beberapa Ruas Jalan di Sekitar Pelabuhan Teluk Bayur Padang", Jurnal Fisika Unand, 3, 198-204 (2014). 